\title{
ПРОДУКТИВНІСТЬ ПШЕНИЦІ ОЗИМОЇ ЗА РІЗНИХ СИСТЕМ ОСНОВНОГО ОБРОБІТКУ ҐРУНТУ В КОРОТКОРОТАЦІЙНИХ СІВОЗМІНАХ ІЗ СИДЕРАЛЬНИМ ПАРОМ
}

\author{
КРИВЕНКО А.І. - доктор сільськогосподарських наук, доцент \\ http://orcid.org/0000-0002-2133-3010 \\ Одеська державна сільськогосподарська дослідна станція \\ Національної академії аграрних наук України \\ почколІнА С.В. - кандидат сільськогосподарських наук, доцент \\ http://orcid.org/0000-0003-2288-9595 \\ Одеська державна сільськогосподарська дослідна станція \\ Національної академії аграрних наук України
}

Постановка проблеми. У землеробстві та рослинництві в останні десятиліття сформувався новий напрям удосконалення технологій виробництва сільськогосподарських культур шляхом уведення інноваційних елементів, який складається з розроблення, упровадження і застосування енерго- i ресурсоощадних технологій, препаратів та удобрення біологічного походження.

Проблема одержання високоякісної зернової продукції потребує вирішення низки технологічних і агротехнічних завдань. Ці завдання доцільніше розв'язувати за допомогою введення органічних елементів до технології вирощування озимих зернових культур.

Отже, виникає необхідність пошуку й упровадження науково обґрунтованих новітніх інноваційних технологій з урахуванням природно-кліматичних особливостей регіону, досвіду вітчизняних і зарубіжних наукових досліджень і підвищення конкурентоспроможності сільськогосподарського виробництва.

Аналіз останніх досліджень і публікацій. Сучасний стан технологій вирощування сільськогосподарських культур в Україні не може забезпечити рослинам абсолютну незалежність чи високий рівень опору до негативних кліматичних явищ, але, без сумніву, адаптація технологій з огляду на агрометеорологічні умови одна з умов раціонального використання матеріальних та енергетичних ресурсів господарства. Основні параметри адаптивності технологій повинні відповідати широкому спектру погодно-кліматичних чинників конкретної зони вирощування.

У зв'язку з порушенням класичних сівозмін в умовах ринкової економіки виникла потреба вивчити різні способи та заходи обробітку чорнозему південного в комплексі з короткоротаційними сівозмінами.

Високі й сталі врожаї зернових озимих культур із високою якістю зерна в умовах Півдня України передбачають удосконалення технологій сільськогосподарського виробництва, оптимізації сівозмін і систем обробітку ґрунту.

Через суттєві зміни кон'юнктури ринку співвідношення галузей рослинництва і тваринництва змістилися, змінилася структура посівних площ, що призвело до значного скорочення площ під горохом і багаторічними бобовими травами, які за правильного обробітку ґрунту є найкращими попередниками для пшениці ози- мої [1; 2]. Беручи до уваги тенденцію звуження спеціалізації більшості сільськогосподарських підприємств, роль попередників як одного з найменш затратних способів оптимізації вирощування озимини тільки зростатиме [3].

Належні умови для вирощування високих і сталих урожаїв пшениці озимої створюють регулювання водного режиму, застосування правильних сівозмін, раціональний обробіток ґрунту, удобрення та вапнування.

Основним критерієм оцінки того чи іншого попередника передусім є врожайність наступної культури.

Дані нашої установи узгоджуються з іншими [4] у тому, що пари чорні $€$ найкращими попередниками пшениці озимої. Так, якщо по парах одержують 100\% зерна, то після зайнятого вико-вівсяною сумішкою $95 \%$, після гороху - 90\%, після ріпаку - 82\%, після пшениці (повторно) - 76\%.

Аналіз продуктивності основних зернових культур за агрокліматичними районами Південного регіону призводе до висновку, що зниження їх урожайності за останніх двадцять років пояснюється проблемами, що виникли внаслідок реформування сільськогосподарської галузі України [5]. Це зумовило те, що за останні роки, наприклад, проявляється тенденція до порушення попередньої структури та розширення повторних посівів озимих.

ОДСДС пропонує більш широко впроваджувати сидеральні пари поряд із чорними [6]. Це один із резервів адаптації до посухи, оскільки сидеральні пари забезпечують урожайність на рівні чорних або й перевищують, але вони підвищують родючість ґрунту, тобто збільшуються запаси гумусу та поживних речовин.

Серед комплексу агротехнічних і організаційно-господарських заходів найважливішу роль відіграють система сівозмін із найбільш раціональним співвідношенням і чергуванням культур залежно від зональних умов і виробничих завдань господарств, а також диференційована система обробітку ґрунту з розширеним арсеналом методів і технічних засобів, яка враховує конкретні умови для оптимального використання існуючих орних угідь.

У сучасних умовах ведення сільського господарства спостерігається тенденція до спрощення обробітку ґрунту, порушення сівозмін і подальшого скорочення кількості внесення добрив [7]. 
Система обробітку ґрунту повинна відповідати агрокліматичним умовам зони, мати головною метою збереження та накопичення вологі в ґрунті, поліпшення поживного режиму ґрунту, захист його від водної і вітрової ерозії, зменшення забур'яненості полів, знищення шкідників сільськогосподарських культур, а також мати ґрунтозахисну спрямованість, базуватися на енергозберігаючих технологіях і бути комплексною за своїм впливом на умови росту, розвитку рослин і формування врожаю.

На думку Л.О. Животкова і багатьох інших науковців, «краще такі умови створюються чергуванням у сівозміні полицевого, безполицевого і мілкого поверхневого обробітків, що сприяє нагромадженню і раціональному використанню води, підвищенню протиерозійної стійкості ґрунту, забезпечує ефективний захист від бур'янів, шкідників і хвороб вирощуваних культур» [8].

За визначенням М.О. Цандура [9] механічний обробіток - «це дія на ґрунт робочими органами знарядь, якими він обробляється 3 метою поліпшення його фізичного стану і знищення бур'янів, загортання добрив і рослинних решток тощо». За способами виконання механічний обробіток поділяється на полицевий, безполицевий, роторний і комбінований, а за глибиною на поверхневий (до 8 см), мілкий $(8-16 \mathrm{~cm})$, середній (16-24 см), глибокий (24-32 см) і дуже глибокий (більше $32 \mathrm{~cm})$ [10].

Але класичний полицевий, а найчастіше багаторазовий і глибокий обробіток ґрунту не завжди відповідає умовам різних природних зон України. У степових районах глибокий обробіток пересохлого ґрунту призводить до зниження врожаю зернових та інших культур, особливо в посушливі роки.

Проти глибокої оранки рішуче виступав І.Є. Овсінський, який був прихильником «сухого поливу» [11]. А на думку Г.М. Чікалікі, «після глибокого ярусного обробітку ґрунту (45-50-75 см) на протязі 6-7 років можна проводити мілкий обробіток ґрунту на глибину 10-15 см» [12]. Протилежну думку мають К. Лубовський і А. Коваленко [13]. Вони вважають, що «глибока оранка покращує стан орного шару за рахунок нижнього структурного шару, у зв'язку з чим у ґрунті накопичується додатково понад 500 м³/га води». Також такої думки дотримуються багато інших науковців, які вважають, що полицевий обробіток ґрунту сприяє створенню більш однорідного за родючістю орного шару» [14; 15].

А.І. Бараєв, І.І. Назаренко, І.А. Тимінський, Г.Н. Лисак, Ю.Н. Поздяков, навпаки, вважають, що землеробство, яке базується на оранці, не захищає ґрунт від ерозії [16-19], тому головне завдання під час обробки ґрунту полягає у тому, щоб обробіток був ґрунтозахисним і ресурсозберігаючим [20-23].

Згідно з даними Ф.Т. Моргуна [24], М.К. Шикули [25] та інших авторів, «безполицевий обробіток чорних парів, окрім ґрунтозахисних властивостей, сприяє додатковому нагромадженню і зберіганню води, зменшенню витрат на його здійснення, збільшенню врожаю озимої пшениці».

Про перевагу безполицевого обробітку ґрунту перед оранкою у фрормуванні весняних запасів ґрунтової вологи свідчать результати досліджень В.О. Єщенко, М.В. Калієвського, П.В. Костогриза та ін. [26].

П.П. Колмаков і А.М. Нестеренко за результатами своїх дослідів дійшли висновку, що «на відносно чистих від бур'янів полях мілкі поверхневі обробітки створюють кращі умови для росту зернових культур і забезпечують підвищення врожайності в перші роки. Але через декілька років забур'яненість поля зростає, і землероб змушений повертатися до глибокої плужної оранки. Тому поверхневі обробітки повинні займати окреме місце в тій чи іншій системі обробітку ґрунту» [27].

На думку науковців Миронівського інституту пшениці В.Ф. Сайко і А.М. Малієнко, «мінімізація обробітку ґрунту як окрема система не є чинником підвищення продуктивності та енергетичної ефективності землеробства» [28].

П.І. Бойко, Є.М. Лебідь та деякі інші науковці стверджують, що найбільш повно відповідає сучасному землеробству диференційована система основного обробітку ґрунту, яка найбільш органічно поєднує у сівозміні чергування різноглибинних полицевих і безполицевих способів обробітку ґрунту залежно від ґрунтово-кліматичних умов і біологічних особливостей сільськогосподарських культур [29].

Таким чином, на озброєнні сучасного сільськогосподарського виробництва $€$ агротехнічні заходи, такі як застосування ресурсозберігаючих, інноваційних технологій вирощування, збільшення питомої ваги високопродуктивних культур у сівозміні. Усе це потребує нового ставлення до цих питань і більш детального вивчення агротехнічної значимості попередників озимих зернових культур.

Мета. Розробити наукові основи оптимізації та адаптації систем сівозмін, основного обробітку ґрунту та ефективних технологій виробництва високоякісної продукції рослинництва в Причорноморському степу.

Матеріали і методика досліджень. Дослідження проводили на протязі 2016-2020рр. на полях Одеської державної сільськогосподарської дослідної станції НААН. Основний метод - польовий, який доповнювався аналітичними дослідженнями, вимірами, підрахунками і спостереженнями відповідно до загальноприйнятих методик та методичних рекомендацій у землеробстві і рослинництві.

У досліді вивчалися система сівозмін (табл. 1) і система основного обробітку ґрунту (табл. 2).

Загальна площа одного поля - 3,6 га, досліду - 18 га. Площа ділянок: по обробітку ґрунту - $2025 \mathrm{~m}^{2}$ (22,5 x 90 м); по попередниках - 2025 м² (22,5 x 90 м); ділянка - 44,7 м² (20,3 x 2,2 м). Повторність 4-разова. Розміщення варіантів методом розщеплених ділянок.

Ділянки 3 обробітком ґрунту розміщуються в напрямку північ-південь, ділянки з попередниками в напрямку схід-захід, тобто попередник накладається поперек обробітку ґрунту.

Експериментальна частина була виконана в чотирьох сівозмінах, які відрізняються тільки першим полем, тобто перша сівозміна починається 3 пару чорного, друга - з пару сидерального з викою, третя - із сумішшю гороху + гірчиця біла на сидерат і четверта - 3 гороху 
Меліорація, землеробство, рослинництво

Таблиця 1 - Схеми сівозмін

\begin{tabular}{|c|c|c|c|c|}
\hline \multirow{2}{*}{$№$ поля } & \multicolumn{4}{|c|}{ Номера сівозмін } \\
\cline { 2 - 5 } & $\mathbf{1}$ & $\mathbf{2}$ & $\mathbf{3}$ & $\mathbf{4}$ \\
\hline 5 & Чорний пар & $\begin{array}{c}\text { Сидеральний пар } \\
\text { (вика озима) }\end{array}$ & $\begin{array}{c}\text { Горох + гірчиця біла } \\
\text { на сидерат }\end{array}$ & Горох на зерно \\
\hline 4 & Пшениця озима & Пшениця озима & Пшениця озима & Пшениця озима \\
\hline 3 & Пшениця озима & Пшениця озима & Пшениця озима & Пшениця озима \\
\hline 2 & Овес & Овес & Овес & Овес \\
\hline 1 & Пшениця озима & Пшениця озима & Пшениця озима & Пшениця озима \\
\hline
\end{tabular}

Таблиця 2 - Схема системи основного обробітку ґрунту в полях сівозмін

\begin{tabular}{|c|c|c|c|c|c|}
\hline \multirow{3}{*}{\begin{tabular}{|c|} 
Умовні позна- \\
чення системи \\
основного \\
обробітку \\
Ґрунту
\end{tabular}} & \multicolumn{5}{|c|}{ № поля сівозміни, культура і пари } \\
\hline & 5 & 4 & 3 & 2 & 1 \\
\hline & $\begin{array}{l}\text { Пар чорний, пари } \\
\text { сидеральні }\end{array}$ & Пшениця озима & Пшениця озима & Овес & Пшениця озима \\
\hline \begin{tabular}{|l|} 
ПММПМ \\
(1-й варіант)
\end{tabular} & $\begin{array}{l}\text { Полицевий, глибокий } \\
22-24 \text { см(П) }\end{array}$ & \begin{tabular}{|l} 
Мілкий, безполиц., \\
8-10 см(М)
\end{tabular} & $\begin{array}{l}\text { Мілкий, безполиц., } \\
\text { 8-10 см(М) }\end{array}$ & $\begin{array}{l}\text { Полицевий глибокий, } \\
\text { 22-24 см (П) }\end{array}$ & $\begin{array}{l}\text { Мілкий, безполиц., } \\
\text { 8-10 см (М) }\end{array}$ \\
\hline $\begin{array}{l}\text { МММПМ } \\
\text { (2-й варіант) }\end{array}$ & $\begin{array}{l}\text { Мілкий, безполиц., } \\
\text { 8-10 см (М) }\end{array}$ & $\begin{array}{l}\text { Мілкий, безполиц., } \\
\text { 8-10 см (М) }\end{array}$ & $\begin{array}{l}\text { Мілкий, безполиц., } \\
\text { 8-10 см (М) }\end{array}$ & \begin{tabular}{|l|} 
Полицевий, \\
глибокий, 22-24 см (П)
\end{tabular} & $\begin{array}{l}\text { Мілкий, безполиц., } \\
\text { 8-10 см (М) }\end{array}$ \\
\hline $\begin{array}{l}\text { БММБМ } \\
\text { (3-й варіант) }\end{array}$ & $\begin{array}{l}\text { Безполиц., } \\
\text { глибокий, 22-24 см (Б) }\end{array}$ & $\begin{array}{l}\text { Мілкий, безполиц., } \\
\text { 8-10 см (М) }\end{array}$ & $\begin{array}{l}\text { Мілкий, безполиц., } \\
\text { 8-10 см (М) }\end{array}$ & $\begin{array}{l}\text { Безполиц., глибокий, } \\
\text { 22-24 см (Б) }\end{array}$ & $\begin{array}{l}\text { Мілкий, безполиц., } \\
\text { 8-10 см (М) }\end{array}$ \\
\hline $\begin{array}{l}\text { MММММ } \\
\text { (4-й варіант) }\end{array}$ & $\begin{array}{l}\text { Мілкий, безполиц., } \\
\text { 8-10 см (М) }\end{array}$ & $\begin{array}{l}\text { Мілкий, безполиц., } \\
\text { 8-10 см (М) }\end{array}$ & $\begin{array}{l}\text { Мілкий, безполиц., } \\
\text { 8-10 см (М) }\end{array}$ & $\begin{array}{l}\text { Мілкий, безполиц., } \\
\text { 8-10 см (М) }\end{array}$ & $\begin{array}{l}\text { Мілкий, безполиц., } \\
\text { 8-10 см (М) }\end{array}$ \\
\hline
\end{tabular}

на зерно. Останні поля у всіх сівозмінах зайняті однаковими культурами. Це зроблено з метою дотримання принципу єдиної різниці і визначення післядії парів і непарових попередників. Овес розміщується як фрітосанітарна культура. Зелена маса сидеральних культур подрібнюється і частково перемішується 3 ґрунтом важкою дисковою бороною (типу БДТ-7, АГД-2,5). Для визначення впливу парів і непарових попередників на врожайність пшениці (дотримуючись принципу єдиної різниці) було прийнято залишити пшеницю повторно і після вівса ( у кінці сівозміни).

Сівозміни накладалися на чотири системи основного обробітку ґрунту (полицева - ПММПМ, безполицева - БММБМ, мілка - МММММ, диференційована - МММПМ).

Облік урожаю здійснювався суцільним методом комбайном «Сампо-500». Бункерну масу зерна, одержану під час обліку урожаю, перераховували на $14 \%$ вологість і $100 \%$ чистоту [30] .

Результати досліджень. Аналіз даних, які були одержані на протязі п'яти років, дає змогу констатувати, що в першій культурі найбільш сприятливі умови для формування врожайності пшениці озимої створюються за розміщення ії після пару чорного і парів сидеральних із викою озимою і сумішшю гороху з гірчицею (табл. 3). Тут був зафіксований майже однаковий урожай зерна, який становив у середньому 4,03, 4,11 і 4,06 т/га відповідно. Різниця між урожайністю не суттєва. Хоча тенденція до збільшення врожайності спостерігається після вики озимої. Перевищення тут становило 2,0\% порівняно з паром чорним.

Найнижчий урожай був отриманий після гороху на зерно, який становив 3,77 т/га, тобто на 6,5\% менше порівняно з паром чорним.

Безполицева система основного обробітку ґрунту (БММБМ) знову зумовила найкращі умови для формування врожайності зерна пшениці озимої першої культури, яка становила у середньому 4,54 т/га, тобто це на $16,4 \%$ більше, ніж за полицевого обробітку ґрунту (табл. 4).

Найгірші показники за врожайністю мав мілкий обробіток ґрунту (ММММM). За даної схеми обробітку ґрунту врожайність зерна пшениці озимої становила 3,60 т/га, тобто на 7,7\% менше, ніж за полицевого обробітку.

Урожайність другої культури пшениці після парів і гороху формувалася на тлі післядії попередників і систем основного обробітку ґрунту, оскільки на другий рік пшениця висівалася лише на тлі мілкого обробітку.

Таблиця 3 - Урожайність зерна пшениці озимої залежно від попередників, т/га (середнє за 2016-2020 рр.), перша культура після парів і гороху

\begin{tabular}{|l|c|c|c|c|c|c|}
\hline \multirow{2}{*}{ Попередник } & \multicolumn{9}{c|}{ Рік } & \multirow{2}{*}{ Середнє } \\
\cline { 2 - 8 } & $\mathbf{2 0 1 6}$ & $\mathbf{2 0 1 7}$ & $\mathbf{2 0 1 8}$ & $\mathbf{2 0 1 9}$ & $\mathbf{2 0 2 0}$ & 4,03 \\
\hline Пар чорний & 6,38 & 3,50 & 3,64 & 4.02 & 2,63 & 4,11 \\
\hline Пар сидеральний (вика озима) & 6,18 & 3,22 & 3,96 & 4,39 & 2,81 & 4,06 \\
\hline Пар сидеральний (горох + гірчиця) & 6,51 & 3,52 & 3,45 & 4,19 & 2,64 & 3,77 \\
\hline Горох на зерно & 6,38 & 3.20 & 3,08 & 3,77 & 2,44 & 4,01 \\
\hline Середнє & 6,36 & 3,36 & 3,61 & 4,10 & 2,63 & 0,19 \\
\hline $\mathrm{HIP}_{05}$ & 0,21 & 0,25 & 0,24 & 0,18 & 0,09 & 0,19 \\
\hline
\end{tabular}


Таблиця 4 - Урожайність зерна пшениці озимої залежно від основного обробітку ґрунту, т/га (середнє за 2016-2020рр.), перша культура після парі і гороху

\begin{tabular}{|c|c|c|c|c|c|c|}
\hline \multirow{2}{*}{$\begin{array}{c}\text { Система основного } \\
\text { обробітку грунту }\end{array}$} & \multicolumn{3}{|c|}{ Рік } & \multirow{2}{*}{ Середнє } \\
\cline { 2 - 7 }$n$ & $\mathbf{2 0 1 6}$ & $\mathbf{2 0 1 7}$ & $\mathbf{2 0 1 8}$ & $\mathbf{2 0 1 9}$ & $\mathbf{2 0 2 0}$ & 3,90 \\
\hline ПММПМ & 6,24 & 3,47 & 3,55 & 3,75 & 2,47 & 3,93 \\
\hline МММПМ & 6,27 & 3,67 & 3,38 & 3,92 & 2,40 & 4,54 \\
\hline БММБМ & 6,88 & 3,88 & 4,19 & 4,81 & 2,94 & 3,60 \\
\hline МММММ & 6,05 & 2,42 & 2,92 & 3,90 & 2,70 & 3,99 \\
\hline Середнє & 6,36 & 3,36 & 3,51 & 4,10 & 2,63 & 0,19 \\
\hline HІР $_{05}$ & 0,21 & 0,25 & 0,24 & 0,18 & 0,09 & \\
\hline
\end{tabular}

Таблиця 5 - Урожайність зерна пшениці озимої залежно від попередників, т/га (середнє за 2016-2020 рр.), друга культура після парів і гороху

\begin{tabular}{|l|c|c|c|c|c|c|}
\hline \multirow{2}{*}{ Попередник } & \multicolumn{9}{c|}{ Рік } & \multirow{2}{*}{ Середнє } \\
\cline { 2 - 8 } & $\mathbf{2 0 1 6}$ & $\mathbf{2 0 1 7}$ & $\mathbf{2 0 1 8}$ & $\mathbf{2 0 1 9}$ & $\mathbf{2 0 2 0}$ & 2,61 \\
\hline Пар чорний & 3,20 & 2,29 & 2,43 & 3,26 & 1,85 & 2,65 \\
\hline Пар сидеральний (вика озима) & 3,17 & 2,21 & 2,79 & 3,26 & 1,82 & 2,63 \\
\hline Пар сидеральний (горох + гірчиця) & 3,45 & 2,39 & 2,46 & 3,15 & 1,70 & 2,45 \\
\hline Горох на зерно & 3,40 & 2,37 & 2,08 & 2,96 & 1,45 & 2,59 \\
\hline Середнє & 3,30 & 2,32 & 2,44 & 3,16 & 1,71 & 0,15 \\
\hline $\mathrm{HIP}_{05}$ & 0,22 & 0,08 & 0,18 & 0,15 & 0,10 & 0,15 \\
\hline
\end{tabular}

Таблиця 6 - Урожайність зерна пшениці озимої залежно від основного обробітку ґрунту, т/га (середнє за 2016-2020 рр.), друга культура після парі і гороху

\begin{tabular}{|l|c|c|c|c|c|c|}
\hline \multirow{2}{*}{$\begin{array}{c}\text { Система основного } \\
\text { обробітку ґрунту }\end{array}$} & \multicolumn{7}{c|}{ Рік } & \multirow{2}{*}{ Середнє } \\
\cline { 2 - 8 } & $\mathbf{2 0 1 6}$ & $\mathbf{2 0 1 7}$ & $\mathbf{2 0 1 8}$ & $\mathbf{2 0 1 9}$ & $\mathbf{2 0 2 0}$ & \\
\hline ПММПМ & 3,59 & 2,36 & 2,49 & 2,80 & 1,57 & 2,56 \\
\hline МММПМ & 3,24 & 2,34 & 2,21 & 3,09 & 1,35 & 2,45 \\
\hline БММБM & 3,28 & 2,33 & 2,76 & 3,50 & 2,04 & 2,78 \\
\hline МММММ & 3,50 & 2,24 & 2,30 & 3.25 & 1,87 & 2,63 \\
\hline Середнє & 3,40 & 2,32 & 2,44 & 3,16 & 1,71 & 2,61 \\
\hline $\mathrm{HIP}_{05}$ & 0,22 & 0,08 & 0,18 & 0,15 & 0,10 & 0,15 \\
\hline
\end{tabular}

Таблиця 7 - Урожайність зерна вівса залежно від попередників, т/га (середнє за 2016-2020 рр.), третя культура після парів і гороху

\begin{tabular}{|l|c|c|c|c|c|c|}
\hline \multirow{2}{*}{ Попередник } & \multicolumn{9}{c|}{ Рік } & \multirow{2}{*}{ Середнє } \\
\cline { 2 - 7 } & $\mathbf{2 0 1 6}$ & $\mathbf{2 0 1 7}$ & $\mathbf{2 0 1 8}$ & $\mathbf{2 0 1 9}$ & $\mathbf{2 0 2 0}$ & \\
\hline Пар чорний & 3,13 & 2,63 & 2,16 & 2,61 & 1,17 & 2,34 \\
\hline Пар сидеральний (вика озима) & 3,32 & 2,62 & 2,38 & 2,60 & 1,38 & 2,46 \\
\hline Пар сидеральний (горох + гірчиця) & 3,23 & 2,48 & 2,24 & 2,46 & 1,03 & 2,29 \\
\hline Горох на зерно & 2,86 & 2,09 & 1,62 & 2,07 & 0,90 & 1,91 \\
\hline Середнє & 3,14 & 2,46 & 2,10 & 2,44 & 1,12 & 2,25 \\
\hline HIP $_{05}$ & 0.17 & 0,14 & 0,16 & 0,16 & 0,11 & 0,15 \\
\hline
\end{tabular}

На другій культурі спостерігалася така ж закономірність, як і на прешій культурі пшениці озимої (табл. 5).

За порівняння врожайності з контролем (паром чорним) спостерігається тенденція до збільшення врожайності на тлі пару сидерального з викою озимою. Хоча врожай зерна на тлі пару сидерального з викою озимою з сумішшю гороху з гірчицею був на одному рівні з урожаєм зерна на тлі пару чорного (261; 2,65 і 2,63/га). На тлі гороху на зерно врожай зерна був нижче на 6,1\% порівняно з паром чорним.

Залежно від систем основного обробітку ґрунту за схемами ПММПМ і МММПМ, а також ПММПМ і МММММ урожайність зерна пшениці озимої в середньому була на однакому рівні, оскільки різниця між варіантами неістотна (табл. 6).
Суттєво вищу врожайність було отримано за схеми обробітку ґрунту БММБМ, яка становила 2,78 т/а, тобто на 8,6\% більше порівняно з обробітком ґрунту зі схемою ПММПМ.

Облік урожаю вівса показує, що тут відзначається майже така закономірність, яка спостерігалася в першій і другій культурах пшениці (табл. 7).

Практично однакові показники за врожайністю були одержані після пару чорного і пару сидерального з викою озимою і пару чорного із сумішшю, які становили 2,34-2,46 т/га, а також 2,34-2,29 т/га. Тут різниця між урожаями несуттєва. Але різниця суттєва між урожаєм на тлі вики озимої і суміші гороху з гірчицею (2,46 проти 2,29 т/га). Найменша врожайність (1,91 т/га) спостерігалася на тлі післядії з горохом на зерно, що на 18,4\% менше, ніж на тлі післядії пару чорного. 
Таблиця 8 - Урожайність зерна вівса залежно від основного обробітку ґрунту, т/га (середнє за 2016-2020 рр.), третя культура після парі і гороху

\begin{tabular}{|c|c|c|c|c|c|c|}
\hline \multirow{2}{*}{$\begin{array}{c}\text { Система основного } \\
\text { обробітку ґрунту }\end{array}$} & \multicolumn{7}{|c|}{ Рік } & \multirow{2}{*}{ Середнє } \\
\cline { 2 - 7 } & $\mathbf{2 0 1 6}$ & $\mathbf{2 0 1 7}$ & $\mathbf{2 0 1 8}$ & $\mathbf{2 0 1 9}$ & $\mathbf{2 0 2 0}$ & 2,64 \\
\hline ПММПМ & 3,23 & 3,19 & 2,48 & 3,17 & 1,14 & 2,32 \\
\hline МММПМ & 3,39 & 2,78 & 1,94 & 2,76 & 0,71 & 2,19 \\
\hline БММБМ & 3,09 & 2,08 & 2,21 & 2,06 & 1,51 & 1,85 \\
\hline МММММ & 2,83 & 1,78 & 1,78 & 1,76 & 1,12 & 2,25 \\
\hline Середнє & 3,14 & 2,46 & 2,10 & 2,44 & 1,12 & 0,15 \\
\hline HІР $_{05}$ & 0.17 & 0,14 & 0,16 & 0,16 & 0,11 & 0 \\
\hline
\end{tabular}

Таблиця 9 - Урожайність зерна пшениці озимої залежно від попередників, т/га (середнє за 2016-2020рр.), четверта культура після парів і гороху

\begin{tabular}{|l|c|c|c|c|c|c|}
\hline \multirow{2}{*}{ Попередник } & \multicolumn{7}{c|}{ Рік } & \multirow{2}{*}{ Середнє } \\
\cline { 2 - 7 } & $\mathbf{2 0 1 6}$ & $\mathbf{2 0 1 7}$ & $\mathbf{2 0 1 8}$ & $\mathbf{2 0 1 9}$ & $\mathbf{2 0 2 0}$ & \\
\hline Пар чорний & 2,97 & 2,26 & 2,37 & 2,78 & 1,51 & 2,38 \\
\hline Пар сидеральний (вика озима) & 3,17 & 2,13 & 2,55 & 2,88 & 1,67 & 2,48 \\
\hline Пар сидеральний (горох + гірчиця) & 3,00 & 2,28 & 2,21 & 2,54 & 1,18 & 2,24 \\
\hline Горох на зерно & 3,03 & 1,91 & 2,14 & 2,36 & 1,01 & 2,09 \\
\hline Середнє & 3,04 & 2,15 & 2,31 & 2,64 & 1,34 & 2,30 \\
\hline HIP $_{05}$ & 0,15 & 0,13 & 0,15 & 0,17 & 0,12 & 0,14 \\
\hline
\end{tabular}

Таблиця 10 - Урожайність зерна пшениці озимої залежно від основного обробітку ґрунту, т/га (середнє за 2016-2020 рр.), четверта культура після парів і гороху

\begin{tabular}{|c|c|c|c|c|c|c|}
\hline \multirow{2}{*}{$\begin{array}{c}\text { Система основного } \\
\text { обробітку ґрунту }\end{array}$} & \multicolumn{5}{|c|}{ Рік } & \multirow{2}{*}{ Середнє } \\
\hline & 2016 & 2017 & 2018 & 2019 & 2020 & \\
\hline ПММПМ & 2,89 & 2,26 & 2,40 & 2,56 & 1,15 & 2,25 \\
\hline МММПМ & 3,22 & 2,12 & 2,15 & 2,35 & 1,01 & 2,17 \\
\hline БММБМ & 3,07 & 2,01 & 2,57 & 3,16 & 1,73 & 2,51 \\
\hline MMMMM & 2,97 & 2,19 & 2,15 & 2,50 & 1,48 & 2,26 \\
\hline Середнє & 3,04 & 2,15 & 2,31 & 2,64 & 1,34 & 2,30 \\
\hline $\mathrm{HIP}_{05}$ & 0,15 & 0,13 & 0,15 & 0,17 & 0,12 & 0,14 \\
\hline
\end{tabular}

Таблиця 11 - Збір зернових одиниць у сівозміні на тлі різних систем основного обробітку ґрунту і попередників, т/га (за 14\%-ї вологості зерна), середнє за 2016-2020 рр.

\begin{tabular}{|c|c|c|c|c|c|c|c|}
\hline \multirow{3}{*}{$\begin{array}{c}\text { Система основного } \\
\text { обробітку ґрунту }\end{array}$} & \multirow{3}{*}{$\begin{array}{c}\text { Культура } \\
\text { після парів }\end{array}$} & \multicolumn{4}{|c|}{ Попередник } & \multirow{2}{*}{\multicolumn{2}{|c|}{$\begin{array}{c}\text { Середнє } \\
\text { по обробітку ґрунту }\end{array}$}} \\
\hline & & \multirow{2}{*}{$\begin{array}{c}\underset{\text { пар }}{\text { чорний }} \\
\text { чор }\end{array}$} & \multicolumn{2}{|c|}{ пар сидеральний } & \multirow{2}{*}{$\begin{array}{c}\text { горох на } \\
\text { зерно }\end{array}$} & & \\
\hline & & & $\begin{array}{l}\text { вика } \\
\text { озима }\end{array}$ & $\begin{array}{l}\text { горох+ } \\
\text { гірчиця }\end{array}$ & & т/ra & $\%$ \\
\hline \multirow[t]{3}{*}{ ПММПМ } & 1 & 3,93 & 3,94 & 3,94 & 3,79 & 3,90 & 100 \\
\hline & 2 & 2,71 & 2,61 & 2,54 & 2,29 & 2,54 & 65,1 \\
\hline & 4 & 2,17 & 2,58 & 2,07 & 2,18 & 2,25 & 57,7 \\
\hline \multicolumn{2}{|c|}{ Середнє } & 2,94 & 3,04 & 2,85 & 2,75 & 2,90 & - \\
\hline \multirow[t]{3}{*}{ МММПМ } & 1 & 3,93 & 4,02 & 4,02 & 3,73 & 3,90 & 100 \\
\hline & 2 & 2,43 & 2,49 & 2,51 & 2,37 & 2,45 & 62,3 \\
\hline & 4 & 2,24 & 2,27 & 2,24 & 1,95 & 2,18 & 55,5 \\
\hline \multicolumn{2}{|c|}{ Середнє } & 2,87 & 2,93 & 2,92 & 2,68 & 2,85 & - \\
\hline \multirow[t]{3}{*}{ БММБМ } & 1 & 4,62 & 4,61 & 4,59 & 4,23 & 4,51 & 100 \\
\hline & 2 & 2,82 & 2,91 & 2,73 & 2,61 & 2,77 & 61,4 \\
\hline & 4 & 2,71 & 2,68 & 2,50 & 2,16 & 2,51 & 55,7 \\
\hline \multicolumn{2}{|c|}{ Середнє } & 3,38 & 3,27 & 3,27 & 3,00 & 3,26 & - \\
\hline \multirow[t]{3}{*}{ MMMMM } & 1 & 3,67 & 3,76 & 3,69 & 3,31 & 3,61 & 100 \\
\hline & 2 & 2,47 & 2,59 & 2,74 & 2,55 & 2.60 & 78,5 \\
\hline & 4 & 2,39 & 2,39 & 2,17 & 2,08 & 2,26 & 68,3 \\
\hline \multicolumn{2}{|c|}{ Середнє } & 2,84 & 2,91 & 2,87 & 2,65 & 2,85 & - \\
\hline \multirow{2}{*}{$\begin{array}{c}\text { Середнє } \\
\text { по попередникам }\end{array}$} & т/га & 3,00 & 3,04 & 2,98 & 2,77 & 2,97 & - \\
\hline & $\%$ & 100 & 101,3 & 99,3 & 92,3 & - & - \\
\hline
\end{tabular}


Полицева система основного обробітку ґрунту зумовила найкращі умови для формування урожаю вівса, який становив 2,64 т/га (табл. 8).

Усі останні варіанти зі схемами обробітку ґрунту МММПМ, БММБМ і МММММ знизили урожай на 12,1, 7,0 і 29,9\% відповідно.

Урожайні дані четвертої культури після парів і гороху на зерно (пшениця озима після вівса) свідчать (табл. 9), що на тлі сидерального пару з викою озимою одержано в середньому на 0,10 т/га (на 4,2\%) більше, тобто тут простежується така ж закономірність, як і в першій культурі пшениці озимої. Хоча різницю тут математично не доведено. Тобто можна вважати, що врожайність на тлі пару чорного і пару сидерального з викою озимою однакова. У даному варіанті найменший урожай також був на тлі гороху на зерно (2,09 т/га).

Способи основного обробітку ґрунту мали позитивний вплив на фрормування урожаю зерна четвертої культури пшениці озимої (табл. 10).

Найбільш ефективним способом обробітку ґрунту виявився безполицевий обробіток (БММБМ), тому що за цієї схеми було отримано найбільший урожай $(2,51$ т/га) порівняно з іншими схемами обробітку ґрунту, що математично доведено. За полицевого і мілкого обробітків ґрунту врожайність пшениці озимої була однаковою і суттєво відрізнялася від урожайності на тлі безполицевого обробітку ґрунту.

Зведені дані за п'ять років по різних попередниках свідчать (табл. 11), що середній збір зернових одиниць за ротацією після пару сидерального з викою озимою, сумішшю гороху з гірчицею і після пару чорного був майже однаковим. Водночас можна відзначити тенденцію до збільшення збору зерна на тлі вики озимої (101,3\% до пару чорного). На $0,7 \%$ за цим показником відставав варіант із сумішшю гороху з гірчицею і на 7,7\% - варіант із горохом на зерно порівняно з паром чорним.

Безполицевий обробіток ґрунту найбільш ефективно вплинув на збір зернових одиниць у сівозміні. У середньому тут було отримано 3,26 т/га, що на 0,36 т/га більше порівняно з полицевим обробітком ґрунту.

Висновки. За всіма варіантами досліду пари сидеральні з викою озимою (2,91 т/га) і сумішшю гороху з гірчицею $(2,87$ т/га) впливають на врожайність пшениці озимої майже на рівні пару чорного (2,84 т/га). На всіх культурах пшениці озимої і вівса позитивний вплив на формування врожайності проявився за безполицевого обробітку (3,26 т/га).

\section{СПИСОК ВИКОРИСТАНОÏ ЛІТЕРАТУРИ:}

1. Методические рекомендации по проведению полевых опытов с зерновыми, зернобобовыми и кормовыми культурами / под ред. В.С. Цикова, Г.Р. Пикуша. Днепропетровск, 1983. 46 с.

2. Перспективи та шляхи удосконалення сівозмін сучасного біологізованого землеробства : посібник українського хлібороба / І.А. Шувар та ін. Біологізація землеробства. 2017. Т. 1. С. 96-103.

3. Жемела Г.П., Шакалій С.М. Вплив попередників на врожайність та якість зерна пшениці м'якої озимої. Вісник Полтавської державної аграрної академії. 2012. № 3. C. 20-22.
4. Панасик М.Г. Урожай та якість зерна озимої пшениці залежно від удобрення та попередників у сівозміні. Вісник аграрної науки. 2005. № 9. С. 72-73.

5. Тимчук В.М. Перспективи біологізації та органічного виробництва : посібник Українського хлібороба: біологізація землеробства. 2017. Т. 1. С. 40-42.

6. Кривенко А.І. Продуктивність пшениці озимої у короткоротаційних сівозмінах 3 сидеральним паром залежно від систем основного обробітку ґрунту та попередників. Зрошуване землеробство. 2016. Вип. 66. С. 161-164.

7. Цандур М.О. Наукові основи землеробства Південного Степу України. Одеса : Папирус, 2006. 180 с.

8. Ресурсозберігаюча і екологічно чиста технологія вирощування озимої пшениці / Л.О. Животков та ін. ; за ред. Л.О. Животкова, О.К. Медведовського. Київ : Урожай, 1992. 224 с.

9. Цандур М., Друз'як В. Адаптивне землеробство Причорномор'я: посібник українського хлібороба : науково-виробничий щорічник. Київ : МАПУ, НААН, ІР ім. В.Я. Юр'єва, 2013. С. 51-55.

10. Загальне землеробство: термінологічний словник / В.О. Єщенко та ін. ; за ред. В.О. Єщенко. Київ : Урожай, 1995. 80 с.

11. Овсинский И.Е. Новая система земледелия. Киев, 1899. $138 \mathrm{c}$

12. Чикалики Г.М. Методические указания по внедрению ярусной системы земледелия и ярусных приемов пахоты. Одеса : ОГСХОС, 1976. 40 с.

13. Лубовский К., Коваленко А. Озимой пшенице - отличную обработку. Земледелие. 1964. № 7. С. 32-34.

14. Круть В.М. Эффрективно использовать орудия для поверхностной обработки почвы. Земледелие. 1981. № 2. C. 29-30.

15. Влагосберегающая обработка почвы в Одесской области / А.В. Тихонов и др. Одесса : Маяк, 1988. $70 \mathrm{c}$

16. Бараев А.И. Защита почв от ветровой эрозии. Москва : Колос, 1964. С. 39-55.

17. Назаренко И.И., Тыминский И.А. О возможности применения безотвальной обработки почвы на Подолье. Земледелие. 1990. № 9. С. 46-47.

18. Лысак Г.Н. Агротехника защищает землю. Челябинск : Юж.-Урал. кн. изд-во, 1983. 89 с.

19. Поздняков Ю.Н. Почвозащитные технологии возделывания культур. Земледелие. 1998. № 9. С. 42-43.

20. Сайко В.Ф., Малієнко А.М. Системи ґрунту в Україні. Київ : ЕКМО, 2007. 44 с.

21. Колмаков П.П. Нужна ли основная обработка почвы в сухой степи. Земледелие. 1986. № 8. С. 26-28.

22. Кононіченко Г.А. Про можливість застосування нульового обробітку ґрунту при вирощуванні окремих польових культур у Південному Степу України. Вісник аграрної науки південного регіону. 2001. № 2. C. 129-132.

23. Крюковских Г.А. Енергозберігаючі ґрунтозахисні технології вирощування сільськогосподарських культур в зрошуваних умовах Криму. Землеробство України в XX1 столітmi : матеріали Всеукр. наук.-практ. конф., 24 травня 2000. С. 112.

24. Моргун Ф.Т. Обработка почвы и урожай. Москва : Колос, 1977. 383 с.

25. Шикула Н.К. Почвозащитная система земледелия: справочная книга. Херсон : Прапор, 1987. 200 с. 
26. Основний обробіток ґрунту під ярі культури в лісостеповій зоні / В.О. Єщенко та ін. ; за ред. В.О. Єщенка. Умань, 2009. 200 с.

27. Колмаков П.П., Нестеренко А.М. Минимальная обработка почвы. Москва : Колос, 1981. 240 с.

28. Сайко В.Ф., Малієнко А.М. Сучасні тенденції формування систем обробітку ґрунту, удобрення і захист сільськогосподарських культур від бур'янів: місце і роль аграрної науки в процесі розвитку АПК України. Київ : Аграрна наука, 2007. С. 154-160.

29. Бойко П.І., Лебідь Є.М. Структура посівних площ і сівозміни в умовах недостатнього зволоження. Пропозиція. 2000. № 7. С. 38-40.

30. Доспехов Б.А. Методика полевого опыта (с основами статистической обработки результатов исследования ; 5-е изд., доп. и перераб. Москва : Агропромиздат, 1985. $351 \mathrm{c.}$

\section{REFERENCES:}

1. Metodicheskie rekomendatsii po provedeniyu polevyih opyitov s zernovyimi, zernobobovyimi i kormovyimi kulturami / pod red. V.S. Tsikova, G.R. Pikusha (1983) [Methodical recommendations for conducting field experiments with cereals, legumes and forage crops], Dnepropetrovsk [in Ukrainian].

2. Shuvar I.A., Ivanishin V.V., Sendetskiy V.M., Trofimchuk O.B., (2017) Bunchak O.M. ta in. Perspektivi ta shlyahi udoskonalennya sivozmin suchasnogo biologizovanogo zemlerobstva: poslbnik ukrayinskogo hliboroba: biologizatsiya zemlerobstva [Prospects and ways to improve crop rotations of modern organic farming: a guide for Ukrainian farmers: biologization of agriculture], Tom 1 [in Ukrainian].

3. Zhemela G. P., Shakaliy S. M. (2012) Vpliv poperednikiv na vrozhaynist ta yakist zerna pshenitsi m'yakoyi ozimoyi. Visnik Poltavskoyi derzhavnoyi agrarnoyi akademiyi [Influence of predecessors on yield and grain quality of soft winter wheat. Bulletin of the Poltava State Agrarian Academy], № 3 [in Ukrainian].

4. Panasik M. G., (2005) Urozhay ta yakist zerna ozimoyi pshenitsl zalezhno vid udobrennya ta poperednikiv u sivozmini. Visnik agrarnoyi nauki [Yield and grain quality of winter wheat depending on fertilizer and crop rotation predecessors. Bulletin of Agricultural Science], № 9 [in Ukrainian].

5. Timchuk V.M., (2017) Perspektivi biologizatsiyi ta organichnogo virobnitstva: posibnik Ukrayinskogo hliboroba: biologizatsiya zemlerobstva [Prospects for biologization and organic production: a guide for Ukrainian farmers: biologization of agriculture], Tom 1 [in Ukrainian].

6. Krivenko A. I., (2016) Produktivnist pshenitsl ozimoyi u korotkorotatsiynih sivozminah $\mathrm{z}$ sideralnim parom zalezhno vid sistem osnovnogo obrobitku Gruntu ta poperednikiv. Zroshuvane zemlerobstvo [Productivity of winter wheat in short-rotation crop rotations with green manure depending on the systems of main tillage and predecessors. Irrigated agriculture], Vip. 66 [in Ukrainian].

7. Tsandur M.O., (2006) Naukovi osnovi zemlerobstva Pivdennogo Stepu Ukrayini [Scientific bases of agriculture of the Southern Steppe of Ukraine], Papyrus, Odessa [in Ukrainian].

8. Zhivotkov L.O., Dushko M.V., Stepanenko O.Ya. ta in., (1922) Resursozberigayucha i ekologichno chista tehnologiya viroschuvannya ozimoyi pshenitsi./za red. L.O. Zhivotkova i O.K. Medvedovskogo [Resourcesaving and environmentally friendly technology for growing winter wheat ], Urozhay, Kiev [in Ukrainian].

9. Tsandur M., Druz'yak V., (2013) Adaptivne zemlerobstvo Prichornomor'ya: posibnik ukrayinskogo hliboroba: naukovo-virobnichiy schorichnik [Adaptive agriculture of the Black Sea region:manual of the Ukrainian farmer: scientific and production yearbook], MAPU, NAAN, IR Im. V.Ya. Yur'eva, Kiev [in Ukrainian].

10. Zagalne zemlerobstvo: terminologichniy slovnik / V.O. Eschenko, V.P. Oprishko, V.P. Gudz ta in. / za red. V.O. Eschenko, (1995) [General agriculture: a glossary], Urozhay, Kiev [in Ukrainian].

11. Ovsinskiy I.E., (1899) Novaya sistema zemledeliya [New farming system] Kiev [in Ukrainian].

12. Chikaliki G.M., (1976) Metodicheskie ukazaniya po vnedreniyu yarusnoy sistemyi zemledeliya i yarusnyih priemov pahotyi [Guidelines for the implementation of a tiered farming system and tiered plowing techniques], OGSHOS, Odessa [in Ukrainian].

13. Lubovskiy K., Kovalenko A., (1964) Ozimoy pshenitse otlichnuyu obrabotku. Zemledelie [Winter wheat-excellent processing. Agriculture] № 7 [in Ukrainian].

14. Krut V.M., (1981) Effektivno ispolzovat orudiya dlya poverhnostnoy obrabotki pochvyi. Zemledelie [Effectively use tools for shallow soil cultivation. Agriculture]. № 2 [in Ukrainian].

15. Tihonov A.V., Garmashov V.N., Scherbakov V.Ya., Sokolov K.K. i dr., (1988) Vlagosberigayuschaya obrabotka pochvyi v Odesskoy oblasti [Moistureretaining tillage in the Odessa region]. Mayak, Odessa [in Ukrainian].

16. BaraevA.I., (1964) Zaschita pochv ot vetrovoy erozii./Zaschita pochv ot erozii [Protecting soils from wind erosion: protecting soils from erosion], Kolos, Moskva [in Russian].

17. Nazarenko I.I., Tyiminskiy I.A., (1990) O vozmozhnosti primeneniya bezotvalnoy obrabotki pochvyi na Podole. Zemledelie [On the possibility of using moldboard-free tillage in Podillia. Agriculture], № 9 [in Ukrainian].

18. Lyisak G.N., (1983) Agrotehnika zaschischaet zemlyu [Агротехника защищает землю], Yuzh.-Ural. kn. izd-vo, Chelyabinsk [in Russian].

19. Pozdnyakov Yu.N., (1998) Pochvozaschitnyie tehnologii vozdelyivaniya kultur. Zemledelie [Soil-protective technologies for the cultivation of crops. Agriculture], № 9 [in Ukrainian].

20. Sayko V.F., MaliEnko A.M., (2007) Sistemi gruntu v Ukrayinl [Soil systems in Ukraine], VD "EKMO", Kiev [in Ukrainian].

21. Kolmakov P.P., (1986) Nuzhna li osnovnaya obrabotka pochvyi $v$ suhoy stepi. Zemledelie [Do I need basic tillage in dry steppe? Agriculture], № 8 [in Ukrainian].

22. Kononichenko G.A., (2001) Pro mozhlivist zastosuvannya nulovogo obrobitku Gruntu pri viroschuvanni okremih polovih kultur $v$ pivdennomu stepu Ukrayini. Visnik agrarnoyi nauki pivdennogo regiona [ On the possibility of using zero tillage in the cultivation of individual field crops in the southern steppe of Ukraine. Bulletin of Agrarian Science of the Southern Region], №2 [in Ukrainian].

23. Kryukovskih G.A., (2000) Energozberlgayuchl Gruntozahisnl tehnologlYi viroschuvannya sllskogospodarskih 
kultur $\mathrm{v}$ zroshuvanih umovah Krimu. Zemlerobstvo UkraYini $v \mathrm{HH} 1$ stollttl. Materlali Vseukr. nauk.prakt. konf, 24 travnya [Energy-saving soil protection technologies for growing crops in irrigated conditions of Crimea. Agriculture of Ukraine in the XXI century. Materials All-Ukrainian scientific-practical. Conf, May 24, 2000] [in Ukrainian].

24. Morgun F.T., (1977) Obrabotka pochvyi i urozhay [Tillage and harvest], Kolos, Moskva [in Russian].

25. Shikula N.K., (1987) Pochvozaschitnaya sistema zemledeliya: spravochnaya kniga [Conservation Crop System: A Reference Book], Prapor, Kherson [in Ukrainian].

26. Eschenko V.O., Kalievskiy M.V., Kostogriz P.V. ta in., (2009) Osnovniy obrobitok Gruntu pid yari kulturi v lisostepoviy zoni / za red. V.O. Eschenka [The main tillage for spring crops in the forest-steppe zone], Uman [in Ukrainian].

27. Kolmakov P.P., Nesterenko A.M., (1981) Minimalnaya obrabotka pochvyi [Minimum tillage ], Kolos, Moskva [in Russian].

28. Sayko V.F., Malienko A.M., (2007) Suchasni tendentsiyi formuvannya sistem obrobitku Gruntu, udobrennya i zahist silskogospodarskih kultur vid bur'yaniv: mistse i rol agrarnoyi nauki $v$ protsesi rozvitku APK Ukrayini [Current trends in the formation of tillage systems, fertilizers and protection of crops from weeds: the place and role of agricultural science in the development of the agro-industrial complex of Ukraine], Agrarna nauka, Kiev [in Ukrainian].

29. Boyko P. I., Lebid E. M., (2000) Struktura posivnih plosch i sivozmlni v umovah nedostatnogo zvolozhennya. Propozitsiya [The structure of sown areas and crop rotation in conditions of insufficient moisture. Offer], № 7 [in Ukrainian].

30. Dospehov B.A., (1985) Metodika polevogo opyita (s osnovami statisticheskoy obrabotki rezultatov issledovaniya. 5-e izd., dop. i pererab [Field experiment methodology (with the basics of statistical processing of research results. 5th ed., Additional and revised], Agropromizdat, Moskva [in Ukrainian].

Кривенко А.І., Почколіна С.В. Продуктивність пшениці озимої за різних систем основного обробітку ґрунту в короткоротаційних сівозмінах із сидеральним паром

Мета. Розробити наукові основи оптимізації та адаптації систем сівозмін, основного обробітку ґрунту та ефективних технологій виробництва високоякісної продукції рослинництва в Причорноморському степу. Методи. Польовий із загальноприйнятими спостереженнями. Результати. Вивчено вплив застосування різних систем основного обробітку ґрунту на врожайність озимої пшениці у короткоротаційній сівозміні. Дослідженнями встановлено, що в умовах Південного Степу України в 1-й культурі найбільш сприятливі умови для формування урожайності пшениці озимої створюються за розміщення її після пару чорного і сидеральних парів із викою озимою і сумішшю гороху з гірчицею. Тут був зафріксований майже однаковий урожай зерна, який становив у середньому 4,03, 4,11 і 4,06 т/га відповідно. Різниця між урожайністю не суттєва. Хоча тенденція до збільшення урожайності спостерігається після вики озимої. Перевищення тут становило 2,0\% порівняно з чорним паром.

Найнижчий урожай був отриманий після гороху на зерно, який становив 3,77 т/га, тобто на 6,5\% менше порівняно $з$ паром чорним.

Зафріксовано, що безполицева система основного обробітку ґрунту (БММБМ) зумовила найкращі умови для формування врожайності зерна пшениці озимої 1-ї культури, яка становила у середньому 4,54 т/га, тобто це на 16,4\% більше, ніж за полицевого обробітку ґрунту. Найгірші показники за врожайністю мав мілкий обробіток ґрунту (МММММ). У 2-й і 4-й культурах пшениці озимої найкраще себе зарекомендував також безполицевий обробіток. Тут урожай становив 2,78 і 2,54 т/ га відповідно. Висновки. За всіма варіантами досліду пари сидеральні з викою озимою (2,91 т/га) і сумішшю гороху з гірчицею (2,87 т/га) впливають на врожайність пшениці озимої майже на рівні пару чорного (2,84 т/га). На всіх культурах пшениці озимої позитивний вплив на формування урожайності проявився за безполицевого обробітку $(3,26$ т/га).

Ключові слова: колосові культури, пар чорний, пар сидеральний, обробіток ґрунту, урожайність.

Krivenko A.I., Pochkolina S.V. Productivity of winter wheat under different systems of basic tillage in shortrotation crop rotations with green fallow

Goal. Develop scientific bases for optimization and adaptation of crop rotation systems, basic tillage and effective technologies for the production of high quality crop products in the Black Sea steppe. Methods. Field with conventional observations. Results. The influence of application of different systems of basic tillage on winter wheat yield in short-rotation crop rotation is studied. Studies have shown that in the southern steppe of Ukraine in the 1st culture the most favorable conditions for the formation of winter wheat yield are created when placing it after a black fallow and green fallow with winter vetch and a mixture of peas and mustard. Almost the same grain yield was recorded here, averaging 4.03; 4.11 and $4.06 \mathrm{t} / \mathrm{ha}$, respectively, $\mathrm{t} / \mathrm{ha}$. The difference between yields is not significant. Although the tendency to increase yields is observed after the winter. The excess here was $2.0 \%$ compared to black fallow.

The lowest yield was obtained after peas for grain, which amounted to $3.77 \mathrm{t}$ / ha, $6.5 \%$ less compared to black fallow.

It is recorded that the subsoil tillage system of basic tillage determined the best conditions for the formation of wheat grain yield of winter 1st crop, which averaged $4.54 \mathrm{t} / \mathrm{ha}$, which is $16.4 \%$ more than in shelf tillage. Deep tillage had the worst yields (in the 2nd and 4th crops of winter wheat, tillage was also the best. Tillage was 2.78 and $2.54 \mathrm{t} / \mathrm{ha}$, respectively). Conclusions. According to all variants of the experiment, sidereal fallow with winter wheat $(2.91 \mathrm{t} / \mathrm{ha})$ and a mixture of peas with mustard (2.87 t/ha) affect the yield of winter wheat, almost at the level of black fallow (2.84 t/ha). On all crops of winter wheat, a positive effect on crop formation was manifested in subsoil tillage (3.26 t/ha).

Key words: crops, black fallow, green fallow, tillage, yield. 